\title{
Editorial
}

1 Ivan Giongo

Assistant Professor, Department of Civil, Environmental and Mechanical Engineering, University of Trento

\section{Jason Ingham}

Professor, Department of Civil and Environmental Engineering, University of Auckland

\section{Maurizio Piazza}

Professor, Department of Civil, Environmental and Mechanical Engineering, University of Trento
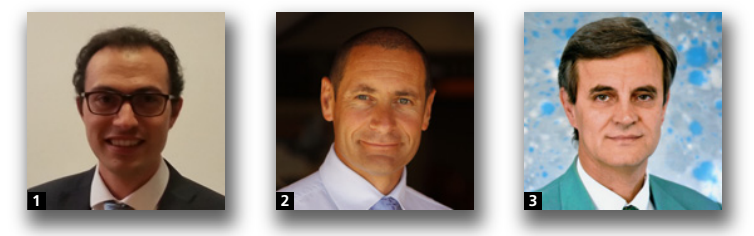

The May 2021 issue of Structures and Buildings is a themed issue on The Role of Structural Timber in the Earthquake Protection of Masonry Buildings - Part I. The themed issue features eight technical papers covering a wide variety of aspects, denoting the centrality and vivacity of the theme and the great interest from the authors. It is therefore a pleasure for us to write this editorial.

In many countries around the World the heritage building stock is largely comprised of unreinforced masonry (URM) buildings with timber roof and floor diaphragms. During earthquakes, these types of structures have proved to be highly vulnerable to lateral loading, with the dynamic response being strongly influenced by timber diaphragm in-plane deformability and the quality of the wall-to diaphragm connections. Understanding the behaviour of timber sub-structures and their interaction with the load-bearing walls is therefore fundamental to the protection of historical buildings in earthquake-prone areas. The characteristics that qualified structural timber as the optimal choice for originally constructing roof and floor diaphragms (i.e. lightweight and high tensile/flexural strength), together with the recent development of new timber-based products (e.g. gluedlaminated timber, laminated veneer lumber and cross laminated timber), make timber suitable also for dry, reversible and minimally invasive strengthening interventions.

The first five papers of the issue, all characterized by a strong experimental basis, explore the strengthening of masonry walls against in-plane and out-of-plane earthquake loading by methods featuring timber-based products. In the opening paper, Pozza et al. (2021) focus their attention on the use of "monolithic, glued or nailed" timber wall panels for the retrofit of masonry walls. The paper presents the outcomes of a testing campaign on two $(0.90 \times 1.40 \times 0.12 \mathrm{~m})$ hollow-brick wallettes loaded in-plane. One of the wallettes was retrofitted with $27 \mathrm{~mm}$ thick timber panels, on either side of the specimen, which were connected to the aluminium beams at the base and at the top of the specimen by using screws. The results of the cyclic tests showed an increase in wallette strength, rocking displacement capacity and energy dissipation capacity. The authors also evaluate the effectiveness of possible variations of the strengthening technique used in the experimental testing by undertaking a numerical study on two masonry façades. The models, calibrated on experimental results available in the literature, appear to confirm the advantages produced by the technique, provided that special care is adopted when connecting the panels to the existing structure.

Borri et al. (2021) report on an experimental programme aimed at investigating the performance increase obtained by applying cross-laminated timber (CLT) panels to the internal side of stone masonry walls and applying steel wire ropes (i.e. Reticulatus method) to the external side. Steel bars (5-6 per square meter of surface) were used as cross-ties to connect the CLT panel to the Reticulatus system on the other side of the wall. Six $1.20 \times 1.20 \times 0.40 \mathrm{~m}$ specimens made of two-leaf ashlar stone masonry were subjected to diagonal compression testing. Three of the specimens were then repaired by sealing the cracks with cement mortar and reinforcing using the combined CLT-Reticulatus technique. After the repair, the specimens were retested by applying the diagonal compression in the opposite direction from that used to test them in the unreinforced condition. Starting from the test outcomes the authors discuss the pros and cons of the proposed combined method for strengthening masonry structures.

The technique studied by Guerrini et al. (2021) sees timber frames connected to masonry piers and to floor diaphragms by means of steel mechanical fasteners. A sheathing layer made of oriented strand board (OSB) sheets was then fixed to the timber frame using nails. The paper describes the mechanical characterization of the performance of such a strengthening technique via in-plane quasi-static shear-compression cyclic testing of two single-leaf calcium silicate masonry piers $(2.20 \times 2.70 \times 0.10 \mathrm{~m})$. One of the two walls was tested in the unreinforced condition and provides the benchmark to assess the effectiveness of the 
strengthening intervention, while the second specimen was tested in the retrofitted configuration directly. The authors report remarkable improvements in the lateral force-displacement response of the retrofitted specimen with 35\% higher strength and $167 \%$ greater displacement capacity.

Giongo et al. (2021) investigate the effectiveness of strengthening/repairing unreinforced masonry (URM) by connecting timber-based panels to one side of the masonry walls by means of point-to-point connections inserted dry. Three URM piers $(\approx 1.80 \times 1.80 \times 0.34 \mathrm{~m})$ located in a century-old building were subjected to in-plane semi-cyclic quasi-static loading. Two of the walls were first tested in the as-built condition and then repaired with a 3-layer CLT panel $60 \mathrm{~mm}$ thick fixed to the masonry via screw fasteners (5-6 per square meter of wall surface). The repaired specimens showed a notable increase in the in-plane capacity while the initial stiffness appears consistent with that of the specimens tested as-built. The third wall tested by the authors was retrofitted prior to any testing and then loaded to its maximum capacity. The authors report an increase of $40 \%$ in the shear-capacity compared to that of the unreinforced walls, with the initial stiffness being comparable with that of the repaired specimens. Both repaired and retrofitted specimens show remarkable energy dissipation and displacement capacity, with drift levels larger than $2.0 \%$.

With the paper by Dauda et al. (2021) the attention is shifted to the out-of-plane response of URM walls strengthened using wood-based products. Specifically, the authors study the opportunity of retrofitting URM walls using OSB sheets and report on the results from the first step taken in such direction. Nine masonry prisms $(0.62 \times 0.22 \times 0.10 \mathrm{~m})$ were loaded out-ofplane in a four-point bending test configuration. Three specimens were tested unreinforced to provide the necessary reference data. Six of the nine specimens were then tested after being strengthened with $18 \mathrm{~mm}$ thick OSB applied to the tension-side of the prism. The OSB sheets were fixed to the masonry by using two connection types: 1) steel threaded-rods and styrenefree vinyl ester hybrid adhesive; 2) steel threaded-rods and nylon expansion anchor sleeves. The authors observed that OSB greatly influences the out-of-plane behaviour of the prisms, resulting in a flexural capacity 5 times to almost 7.5 times higher than that of the unreinforced specimens.

The sixth paper by Abdel-Aty (2021) concentrates instead on the role played by the timber-ties present in URM arcade buildings constructed in Egypt during the Medieval period, in the successful survival of such historical buildings to the modern times. The timber-ties connect the masonry arches constituting the building arcades at the level of the column heads. According to the author's research, timber-ties were also used to connect the arcades perpendicular to the arch orientation and to stabilize tall, slender walls against possible instability. The paper includes the results obtained from limited experimental investigation and from extensive finite-element numerical analysis of two case-study buildings representative of historical medieval buildings in Cairo. The author, subsequently to the study of the seismic stability of parallel-arcade and cross-arcade structures with timber-ties, proposes a solution for strengthening parallel-arcaded buildings by introducing cross-bracing high-strength steel bars to supplement the stabilizing action provided by the timber-ties.

As previously mentioned, the accurate knowledge of the behaviour of the timber sub-structures already present in traditional buildings, such as roofs and floors, and their interaction with the load-bearing walls is basic to the seismic protection of the built heritage. In this regard, Parisi and Tardini (2021) present a study on timber roof-structures. The authors isolate the main factors contributing to the vulnerability of timber roofs when subjected to earthquake loading and discuss a procedure to guide the seismic assessment of such structures. The procedure starts with an initial visual inspection to collect the data and information on the parameters relevant to the seismic performance of the roofs. Then the roof structures are classified according to a grading system that goes from grade A, of sound roofs with safety levels consistent with those of code designed structures to grade D of highly vulnerable structures. The authors affirm that so far in the case-studies where the procedure has been applied, it has proven to be a useful tool to draw attention to the seismic qualification of timber roof structures that were conceived with sole regard to gravity loads and as such are often inadequate to resist lateral loading.

With the paper by Keller et al. (2021) the focus stays on timber roofs. The authors describe the outcomes of a numerical study aimed at evaluating how the roof structure typology can influence the seismic behaviour of masonry buildings. Three different roof structure types, representative of eighteenth, nineteenth and twentieth century Romanian roofs, are simulated via finite element modelling. A three-storey building from the eighteenth century serves as case-study for assessing the roof-type impact. In the simulations the authors consider alternative scenarios concerning the quality and the performance of the roof-to-masonry connections and the traditional carpentry joints. The analysis results are then compared in terms of lateral displacements at the top of the building, interstorey drifts and damage levels.

We firmly believe that the readers of Structures \& Buildings will find this themed issue both informative and stimulating. Discussions or comments on any of the papers are welcomed and instructions on how to contribute can be found on the papers' last page.

\section{REFERENCES}

Abdel-Aty YYA (2021) Roles of timber tie-rods to reduce seismic vulnerability of historical buildings in Egypt. Proceedings of the Institution of Civil Engineers - Structures and Buildings 174(5): 418-430, https://doi.org/10.1680/jstbu.19.00091. 
Borri A, Sisti R and Corradi M (2021) Seismic retrofit of stone walls with timber panels and steel wire ropes. Proceedings of the Institution of Civil Engineers - Structures and Buildings 174(5): 359-371, https://doi.org/10.1680/jstbu.19.00100.

Dauda JA, Lourenço PB and luorio O (2021) Out-of-plane testing of masonry walls retrofitted with oriented strand board timber panels. Proceedings of the Institution of Civil Engineers Structures and Buildings 174(5): 403-417, https://doi.org/10.1680/ jstbu.19.00095.

Faggiano B, lovane G, Marzo A et al. (2021) Reinforcement of ancient floors by timber-concrete composite systems with collar connector. Proceedings of the Institution of Civil Engineers Structures and Buildings, https://doi.org/10.1680/jstbu.19.00105.

Giongo I, Rizzi E, Riccadonna D and Piazza M (2021) On-site testing of masonry shear walls strengthened with timber panels. Proceedings of the Institution of Civil Engineers - Structures and Buildings 174(5): 389-402, https://doi.org/10.1680/jstbu.19.00179.

Gubana A and Melotto M (2021) Discrete-element analysis of floor influence on seismic response of masonry structures. Proceedings of the Institution of Civil Engineers - Structures and Buildings, https://doi.org/10.1680/jstbu.19.00099.
Guerrini G, Damiani N, Miglietta M and Graziotti F (2021) Cyclic response of masonry piers retrofitted with timber frames and boards. Proceedings of the Institution of Civil Engineers - Structures and Buildings 174(5): 372-388, https://doi.org/10.1680/jstbu.19.00134.

Keller Al, Parisi MA, Tsakanika E and Mosoarca M (2021) Influence of historic roof structures on the seismic behaviour of masonry structures. Proceedings of the Institution of Civil Engineers Structures and Buildings 174(5): 443-456, https://doi.org/10.1680/ jstbu.19.00098.

Parisi MA and Tardini C (2021) Seismic vulnerability assessment of timber roof structures: criteria and procedures. Proceedings of the Institution of Civil Engineers - Structures and Buildings 174(5): 431-442, https://doi.org/10.1680/jstbu.19.00097.

Pozza L, Marchi L, Trutalli D and Scotta R (2021) In-plane strengthening of masonry buildings with timber panels. Proceedings of the Institution of Civil Engineers - Structures and Buildings 174(5): 345-358, https://doi.org/10.1680/jstbu.19.00121.

Trutalli D, Marchi L, Scotta R and Pozza L (2021) Seismic capacity of irregular unreinforced masonry buildings with timber floors. Proceedings of the Institution of Civil Engineers - Structures and Buildings, https://doi.org/10.1680/jstbu.19.00115. 